small patch of recent ringworm, would be both useless and unjustifiable if applied to a large surface of chronic ringworm or to the disseminated variety. I do not for a moment think I can cure ringworm more quickly than other men; but I do maintain that no end of cases are said to be cured when the disease is only in its most ordinary chronic form. Thus the doctor who certifies such cases to bo well gets the credit of quickly curing ringworm; while those who refuse to certify if there are any diseased stumps remaining (and it is often most difficult to detect them) are thought not to be able so successfully to cope with the disease.

I cannot close without a few remarks upon your most excellent leading article, especially about the fact that "probably not 3 per cent." of hospital cases "are seen to their complete recovery," if it ever take place before puberty; and thus, to poor people, ringworm is "practically incurable in chronic stages." It is, as you remark, "of the first importance that the appearances in the more chronic forms of ringworm of the scalp should be readily recognised." There is no doubt whatever that children still suffering from this disease are frequently sent back both to public and private schools, even with medical certificates. After a long experience with regard to "certificates," I most fully endorse every word you say. Scarcely a week passes but I examine children for admission into private schools who have obtained certificates from medical men that they are free from ringworm, but who are still suffering from it in a most chronic form. Medical men of the highest professional standing often make the mistake of thinking ringworm is cured because the hair is growing freely on the affected places. There is no greater fallacy, for the most obstinate forms of this disease are those where the hair has grown again on the places, but where a few diseased stumps are still to be detected with a lens among the long hairs. The diagnosis of chronic ringworm is easy enough provided the medical man knows what to look for. My advice is to take no special notice of scurf, or whether the long hairs are growing firmly or not. Scurf may exist in patches and long hair may come out easily without ringworm being present; and, again, there may be severe chronic ringworm, and yet the long hairs on the patches may be quite firm and but little scurf may exist. The only diagnostic sign of any value is the presence, or the absence, of short broken-off diseased hairs called stumps. Ringworm rarely exists (except in the earliest stages) without a few broken-off hairs boing visible; and certainly if there are any left the case is not cured, and the child may give the disease to others. Diseased stumps can generally be easily recognised, without the aid of the microscope, by noticing whether they break off on attempted epilation with a pair of forceps. If the stumps break off easily, leaving the root part behind in the follicle, there is but little doubt the case is one of ringworm; but if they come out with the roots entire and atrophied, it may be alopecia only: the microscope will settle the question.

I trust my long experience with this most troublesome and often intractable complaint will excuse these somewhat dogmatic remarks. - I am, Sirs, yours obediently,

Christ's Hospital, May 27th, 1887. ALDER SMITH.

\section{ECONOMY IN THE WARDS.}

\section{To the Editors of THE LANCET.}

Sins,-The embarrassed condition of the funds of many hospitals, large and small, has led to all sorts of expedients for cutting down working expenses. Reform in our expenditure is becoming a favourite cry, and the shifts that many institutions have had, perforce, to resort to for some time past will become almost universal. There is one department in which I am sure great saving with a little care might be effected, and that is in connexion with the materials employed in antiseptic dressings. I was brought up at the feet of Gamaliel, so to speak, under a master who enforced the most rigid attention to every detail of Listerism, and woe betided the unfortunate dresser who omitted the smallest portion of the mystic ceremonies that were pursued at every bedsidesuch washings, and purgings, and scaldings, and sprayings, that one left the hospital daily with one's hair and skin impregnated with pungent odours, that were ineffaceable, and which were carried out to the theatre or dinner party, to the disgust of one's neighbour and the discomfort of one- self. On leaving London I became house surgeon to a country infirmary, where sepsis and poultices were the order of the day, and stinking stumps and fetid fractures rendered the wards almost unbearable. By the courtesy of the visiting staff I was allowed to act the part of the proverbial new broom, and certainly I did make a clean sweep of some of the smells. But when the bills came in for the gauze and the salicylic wool, the pounds-shillings-and-pence argument came into play with the board, who could not be made to understand the abnormal rise in their expenses. Our finances were limited, and $I$ had to cast about to see in what direction a saving could be made. In fear and trembling, I first discarded the salicylic wool, substituting ordinary wadding, with no evil results; then, in a rash moment, I dispensed with the gauze, using instead Gamgee tissue, but without the wounds becoming septic; then the green "protective" went the way of the gauze, and a strip of carbolised oiled lint took its place; and, lastly, to the intense relief of my cracked and frozen fingers, I abandoned the spray. In fact, I gradually threw overboard every detail of Listerism as then practised, without the least bad result. Accidents of the most serious kind were frequent, it being a great railway centre; and, with compound fractures and tolerably frequent injuries requiring amputations, the test was ample and sufficient. I can unhesitatingly affirm that with a preliminary cleansing with a solution of carbolic or corrosive sublimate-of course, seeing that all the instruments were carefully cleanedamputations were performed without the spray, the wound covered with iodoform powder, two or three thick pads of Gamgee tissue applied, outside that a quantity of oakum with a common calico roller, and the results were as uniformly satisfactory, and perhaps more so, than we had before under the more complex and certainly far more expensive system of prepared dressings ; in fact, the simpler the dressing used the better the wounds seemed to do. I could quote a dozen cases of the most serious injuries where it was of vital importance to exclude suppuration, and where, with no more precaution than careful ablution and a sufficiency of soft absorbent material for dressing, primary union took place without a rise of temperature or the least discomfort to the patient. I found wood-wool by far the best dressing; its cost was very little, and pads of it covered with old linen formed an all-absorbing covering. The saving to the hospital was immense; indeed, we could not have afforded Listerian dressings as then practised. I am not advocating a return to the old days of water dressings, \&c.; I firmly believe in antiseptic dressings, but, I am perfectly sure that in our hospitals, daily and weekly, pounds are wasted in precautions that could be dispensed with. 1 have carried out the same treatment in private practice, and with the aid of iodoform, common lint, and tenax, have secured as good surgical results as we used to do with layer on layer of gauze, protectives, prepared wools, and special bandages. The hospital I speak of was not in a particularly bealthy town, and our sanitary arrangements at one time were very bad. I know it is said that these results cannot be obtained in London. That that is erroneous is shown by some of the remarkable results achieved by men who use far less precautions than I did. Of course, where economy is no object (and I judge that there are very few hospitals where that could be said), or in those where a certain formula for wound dressing is obligatory, this economy of dressings is not to be expected; but I am sure that, were the actual cost of the materials employed in some of our wards during a year published, the figures would astonish the natives and foreigners alike. I am, Sirs, yours obediently,

June, 1887. J. G. Marshal, M.B. Cantab., M.R.C.S.

\section{THE UTILITY OF DRUGS IN THE TREATMENT OF DISEASE. \\ To the Editors of THE LANCET.}

SIRs,-In my green and salad days I, like many others, fell away from the scholastic belief in the utility of drugs, my apostasy to a great extent being due to a blind heroworship and following of the investigations of Sir William Gull into the treatment of rheumatic fever. Does he still hold that the temperature in this fever cannot be lowered by salicine, and that it matters not to the result whether we use this valuable and certain antipyretic or give 
mint-water? Nust we now shut our eyes to the brilliant investigations of Brunton, Murrell, Frazer, Rutherford, Fothergill, Garrod, and a host of other recent writers, who without doubt show that this epoch in the history of practical medicine is more remarkable than any other for the unbounded and intelligent faith which scientific practitioners have in the utility of drugs in the treatment of disease? Is this warm bed to replace the surgery, and the warming-pan the hypodermic syringe? Everyone must admit that it is bad to give too much medicine, but what is worse than the trade mark on the prescription is the taint of empiricism. This, we hope, is passing away.

We now know how quinine cures neuralgia; how the bromides and chloral give sleep; how digitalis may be given so as to act on the kidney, strophanthus on the heart, amyl on certain peripheral blood areas, pilocarpine on the sweat glands, ergot on the arterioles of the lungs and uterus, \&c. By the light of this more exact and fuller knowledge we have come, by slow but sure steps, to believe more implicitly than our fathers did in the action of remedies, and to ignore that panacea of ignorance, "expectancy." Our drugs are purer and more elementary, our prescriptions simpler and more scientific; and, with his hypodermic syringe and the long array of accredited alkaloids, the physician not only trusts more to the action of his remedies, but even dares to look forward to the time when his art will be based on scientific certainty. It may or may not be true (for it is still sub judice) that vaso-motor pathology justifies Sir William's beautiful theory of arterio-capillary fibrosis; but no one can deny that to vaso-motor therapeutics the general practitioner owes much of that calm faith and comfort at the bedside which is the aim of all true rational medicine. am a general practitioner and dispense my own prescriptions, but I claim as high a platform as any consultant, be

the who he may, who is content to ignore the light which is now flooding the field of therapeutics.

I am, Sirs, yours truly,

Rothwell, Northamptonshire, May 29th, 1887. JAMES MORE, M.D.

\section{THE CONTAGIOUS DISEASES ACTS IN INDIA.} To the Editors of THE LANCET.

Strs,-In your issue of April 16th, page 792, you furnish a few remarks on this topic. The following facts emphasise in a remarkable degree the gist of your observations. Lock hospitals were introduced into India in 1866. Following their establishment the ratio of venereal disease in the army fell in a most remarkable manner, so much so that in 1873 the ratio per mille was 1667 ; from then till 1877 the reduction was stationary. From 1877 to 1884 there appeared a steady increase in the ratio. This increase was made the reason for a determined onslaught on the existence of lock hospitals. It was chiefly in consequence of the discredit thrown on these institutions by the late Sanitary Commissioner with the Government of India, in his yearly statistical comments, that an experimental reduction in their number was ordered to take effect from the early part of 1885. It was then that we saw a truly marvellous increase in the venereal ratio. The excess of the 1885 rate over that of the preceding ten years was 1920 per mille in the experimentally unprotected stations and 61.2 in the protected. The outcome of this experimentally closing of some of the lock hospitals in $1884-5$ was that $1300^{\circ} 8$ per mille of the troops in cantonments where the lock hospital was closed contracted disease; the same, had the hospital been left open, would have escaped. So conclusive have these facts been that the Government of India have recently reopened all the lock hospitals which had been experimentally closed. It is probable that several causes exist for the relative increase of venereal disease in the Indo-European army apart from the closure of some lock hospitals. They appear to be-(1) a larger proportion of young men in the ranks; (2) a larger number of inexperienced men; (3) a lesser number of married men; (4) the increase of cold weather manœurres; (5) the improved general health of the army, which is consistent with greater prevalence of sensual desire. Factors though these may be, their existence in no way vitiates the value of lock hospitals in the cantonments of India, but rather points to the necessity for the continued establishment of every precaution against venereal risks.

I am, Sirs, yours faithfully,

Dagshai, May 2nd, 1887

R. H. FirTH, F.R.C.S. Eng., Surgeon, A.M.S.

\section{MR. WARRINGTON HAWARD'S CASES OF} TRANSFUSION.

To the Editors of THE LANCET.

SIRS,- - In a recent number of THE LANCET there appeared a communication from Mr. Warrington Haward, describing a method of transfusion which he had successfully employed in a case of hæmorrhage. Mr. Haward is evidently under a misapprehension as to the authorship of the method in question. In June, 1883, my friend, Mr. J. M. Cstterill, was good enough to perform transfusion on a patient of mine This he did, with complete success, by the method which Mr. Haward has carefully described. Recognising the great merits which this method possesses, Mr. Cotterill strongly recommended it to other surgeons bere, who, like himself, have since frequently performed it with marked success, While Mr. Annandale, Mr. John Duncan, and many other surgeons, here and elsewhere, who have since that date performed transfusion by Mr. Cotterill's method, have testifled to its ease and safety, it is here well recognised that the credit is due to Mr. Cotterill for having brought the methol under the favourable notice of the profession.

I am, Sirs, yours faithfully,

Edinburgh, May 21th, 1887.

J. Grafam Brown, M.D.

\section{"A D O C T O R'S I N C O II E."}

To the Editors of THE LANCET.

SrRS,-Dr. Paget Thurstan, in his letter of May 21st, suggests that county hospitals are one of the causes which contribute to the under-payment of the great mass of the medical profession. With this suggestion I entirely agree, but altogether dissent to his proposed remedy. Dr. Thurstan suggests that the general practitioner should be allowed to follow his cases to the hospital, and should receive for so doing exactly the same fees as he would have received for attending the patient at his own home. He forgets that a large proportion of the inmates of our hospitals are men, and that their families, deprived of the weekly wages, hare great difficulty in providing the daily loaf, and would be quite unable to pay a doctor remunerative fees. Again, a large percentage of the patients are drawn from the surrounding villages, making it impossible for the country practitioner to drive of ten several miles to the neighbouring town, quite out of his usual round, to visit his patient in the hospital. It is not the in-patient departments of our county hospitals which injure the general practitioner, but the out-patient. In the present day the wives and daughters of small farmers, tradesmen, and well-to-do working men are most frequently allowed to attend the out-patient department without any question being asked them. They have learnt and are teaching other to seek their county hospitals when they are well enough to make the journey, and to fall back on the country practitioner when they are too ill to leave their own homes. The remedy lies with the medical profession. Throughout the kingdom we have our medical societies, which meet st various intervals during the year. Why should not this question of hospital abuse and other similar questions affecting the profession at large be freely discussed at such meetings? If this were done, hospital physicians and surgeons would realise more fully than they yet have the gross injustice they inflict on the general practitioner by treating in their own out-patient rooms at the hospital, without making any kind of protest, patients who are well able to pay their own doctor moderate fees which would remunerate him for his services. I would further suggest that it would be a good opportunity, now that the subject is exciting a great deal of interest, to arrange for a discussion of the question at the next annual meeting of the British Medical Association in August.

I am, Sirs, yours truly, Hon. Physician, Radeliffe Infirmary, Oxford.

\section{To the Editors of THe Lanoet.}

Sirs,-The happy idea of Dr. Paget Thurstan in bringing out so lucidly the inner life of the profession deserres all praise. But there is a point not brought out fully in his letters to THE LANCET. I mean the estimate put by the 